\title{
Water challenges and Urban Sustainable Development in Changing Climate: Economic Growth Agenda for Global South
}

\author{
Tabassam Raza ${ }^{1,2,3,4}$, Frederika C. Rentoy ${ }^{3}$, Nisar Ahmed ${ }^{5}$, Andrea Valentine L. \\ Andres $^{3}$, Thess Khas S. Raza ${ }^{3}$, Karl Michael E. Marasigan ${ }^{4}$ and \\ Ramon Iñigo M. Espinosa ${ }^{1}$
}

\begin{abstract}
Access to safe clean water and sanitation were pressing concerns for survivors after super Typhoon Haiyan devastated central Philippines in November 2013. Essentially, water problems in the cities of Global South especially in Southeast Asian Archipelagos (Philippines, Indonesia, and Malaysia) plus Myanmar and Thailand are viewed as the consequence of uncontrolled rapid urban development and Climate Change (CC) variations. These facts emphasized the link between water insecurity and its negative economic impact. Thus, an equal and inclusive agenda is developed without which universal access to drinking water, sanitation, and hygiene is not possible. It comprises of conducting gendersensitive strategic planning workshops and strategic spatial analysis using Geographic Information Systems. It was implemented to Quezon City (QC), Philippines as pilot. The output is an action plan defining 15 Programs, Projects and Activities (PPAs) as solutions for water challenges across five development sectors (Social, Economic, Environmental, Land Use/Infrastructure, and Institutional) in the Philippines context. The appropriate implementation of these PPAs will ensure QC's sustainable development, CC-resiliency, and its contribution to the country's economic growth. The framework used is flexible and can be fashioned for the other cities in Global South countries and other regions.
\end{abstract}

Keywords: Sustainable Development, Climate Change, Inclusive, Economic, Action Plan

\section{Introduction}

After super Typhoon Haiyan hit and devastated central Philippines on November 8, 2013, access to safe and clean water and to sanitation were pressing concerns for survivors. Total damage for the public water sector was estimated at US\$69.8 million, with almost 86 per cent of the costs due to damages to private household connections, equipment and operations loss. It served as a wake-up call for urgent action by the Philippines (Raza et al, 2018). In addition, cities in Southeast (SE) Asian Archipelagos (Philippines, Indonesia, and Malaysia) and Small Island Developing States (SIDS) have distorted the natural environment by haphazardly constructing roads, buildings, and other related infrastructures. Essentially, the continuous influx of people migrating from rural areas to urban areas and natural population growth in urban areas increases the demand for people's welfare; expected spatial and temporal changes are

\footnotetext{
${ }^{1}$ Disaster Risk Management Unit, Graduate School of Business, Philippine School of Business Administration, Manila, Philippines

${ }^{2}$ U.P. Planning and Development Research Foundation, Inc. Quezon City, Philippines

${ }^{3}$ Environmental Protection and Waste Management Department, Quezon City Government, Philippines

${ }^{4}$ Quezon City Disaster Risk Reduction and Management Office, Quezon City, Philippines

5Provincial Disaster Management Authority, Lahore, Punjab, Pakistan
} 
consequently distressing water sufficiency. According to Asian Water Development Outlook by Asian Development Bank in 2016 explained that there is growing evidence of the link between water insecurity and the drag it places on the economy. Further, the advent of the post-2015 development agenda and a dedicated Sustainable Development Goal for water reflects this message and reemphasizes the inter linkages of this finite resource across a range of users (ADB, 2016). Asia and the Pacific cannot sustain economic growth unless water is brought into the equation. Such massive changes in the environment are altering the ecology, creating challenges for sustainable development such as local flooding and water pollution. Mainly, the urban development and related water problems in SE Asian cities are viewed as the consequence of climate change variations impact and rapid and uncontrolled urbanization and unsustainable development. Population growth rates in the urban centers handicap the countries from attaining the economic targets normally set out in 5-year or 10-year development plans (Sim and Balamurugan, 1989). The continuous increase in population congestion also has serious implications in terms of shortages in amenities such as water supply and sanitation problems are impossible to solve in short term. Further, the quest for economic advancement had fabricated a disregard for environmental conservation, which, in turn, has resulted in water problems of considerable magnitude and need to be resolved achieving regional water security. That is more than just providing sufficient water for people and economic activities. It is also about having healthy aquatic ecosystems and protecting us against water-related disasters (ADB, 2016). According to the International Institute for Applied Systems Analysis (IIASA) in 2016, Asia and the Pacific is the global hot spot for water insecurity. The International Institute for Applied Systems Analysis has prepared the Asian Water Futures and Solutions 2050 report which provides initial estimates that up to 3.4 billion people could be living in water-stressed areas of Asia by 2050. Thus, there is an Urgent need for a more equal and inclusive policy objective, without which, the Sustainable Development Goals and Climate Change themes for universal access to drinking water, sanitation, and hygiene cannot be achieved. This research used extensive desk study methodology to identify and know the causes of the water problems due to urbanization and Climate Change variability. Only, primary data for Quezon City of the Philippines is collected to justify the overall argument. Thus, this paper is significantly based on the availability of pertinent secondary data to explore indicative solutions and key action points that may prevent if not totally eliminate the water problems and become potential contributor in achieving Paris Agreement and Sustainable Development Goals (SDGs) up to 2030.

\section{Relating Urban Activities and Climate Change Variability to Water Demand}

Cities in SE Asia are ballooning, and the accompanying upsurge in the consumption of water and production of waste in urban areas are placing new pressures on the environment. Fast economic growth, coupled with breakneck urbanization, climate change phenomena and changing lifestyles, has made a difficult situation worse. The region's CC variation's impact and urbanization is fueling demand for water not just for cities' use but also for manufacturing and agriculture activities. Business-as-usual is not possible anymore. Further, strengthening governance is undeniably the major 
requirement for effective resource management and sustainable development. According to Sim and Balamurugan (1989), the Southeast (SE) Asia urban water problems come under two contrasting categories: first, problems caused by underdevelopment of the available resources; and, second, problems caused by activities aimed at economic development. The simultaneous existence of these two contrasting categories raises a lot of questions. In addition, the water quality and water supply reliability are jeopardized by climate change in a variety of ways that affect ecosystems and livelihoods (NOAA, 2018). Given the ever-increasing urbanization and population growth, the urban water problems in SE Asia are expected to escalate rather than attenuate unless serious planning and management are carried out.

\section{Problems Caused by Uncontrolled Urban Growth and Climate Change Variability}

Many challenges faced due to uncontrolled urban growth and Climate variability, including changes in temperature, evaporation, and precipitation, impacting regional water resources and expected to increase the frequency of floods and droughts and reduce river flows, particularly during low flow periods. The three main problems caused by above challenges and worth discussing are water pollution, water depletion, and flooding.

\subsection{Water Pollution}

From streams to region wide river channels, the Southeast Asian region hosts dozens of rivers. The most known river in Southeast Asia is the Mekong River spanning five countries in the region itself. The Mekong, which is also the 12th longest river in the world, is known to be a major water source for drinking, fishing and agricultural needs for millions of people. What many do not know about it however, is that it is also a dumping ground for garbage and waste deposits making it to be one of the most polluted rivers in the region. Many rivers in the region are highly polluted with domestic, industrial and agricultural waste thus causing the Water Quality Index (WQI) to reach unsafe levels. The Marilao River flows through Metro Manila in the Philippines. Its pollution is one of the major causes of concern for both, the government of Philippines as well as for the world. Hazardous non-recyclable objects such as plastic bottles and rubber slippers, amongst others are commonly found floating on the river. Moreover, toxic industrial waste products are also dumped into the river each day and household garbage is also discarded in huge quantities (Victor, 2017). Another headlining river in the region is the Citarum river that flows through the Indonesian province of West Java. The Citarum river is an important resource which aids in agriculture, water supply, industry, fishery, and production of electricity. The other rivers in the region that are facing pollution include the Irrawaddy river in Myanmar, Chao Phraya in Thailand and the Kinabatangan in Malaysia. Causes and effects behind the pollution are similar between these and other rivers in the region. 


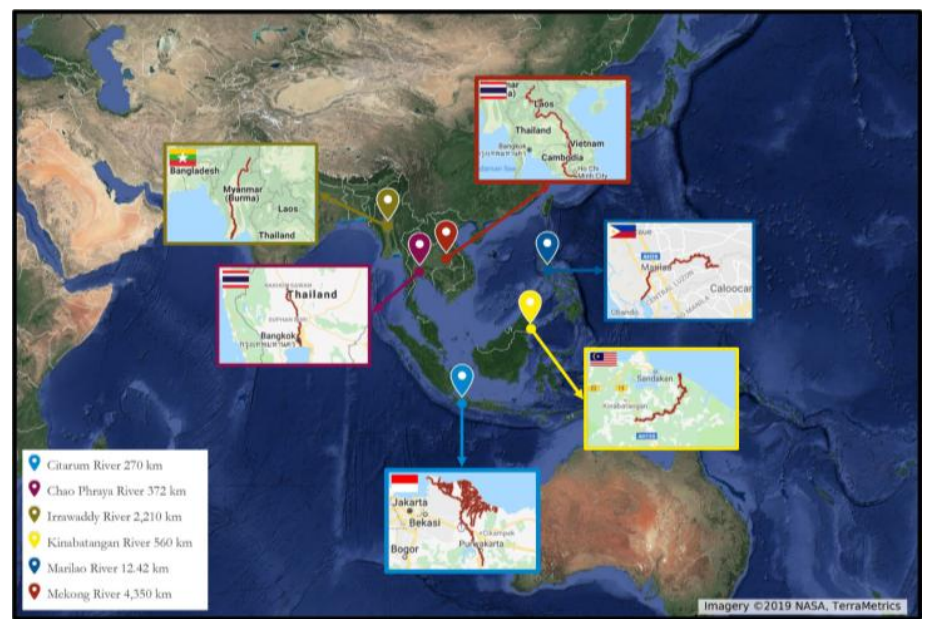

Figure 1. Location of major polluted rivers in Southeast Asia. (Modified after Victor, 2017)

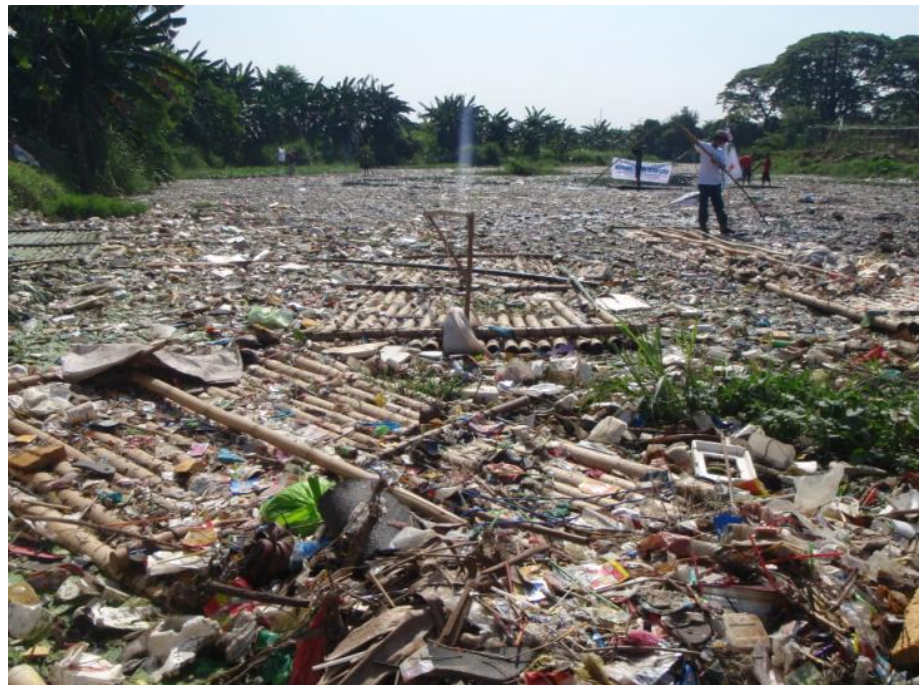

Figure 2. Workers collects garbage from the Marilao River in Manila, Philippines.

Photo Credit: Maletsky, F., Zamboanga.com

Based on the Institute for the Advanced Study of Sustainability's Policy Brief report, pollution levels in Metro Manila's rivers are so high that "they could be considered open sewers." The main cause is the untreated residential waste that flows directly into the water bodies. According to official statistics, only 20-30 percent of the city's households are connected to a sewerage system. The remaining 70 percent of households have septic tanks, which in many cases leak human waste into underground aquifers.

The bursting population is a reason for insufficient water per head. Water in most rivers is polluted, making it unfit for drinking or any other use. The poor quality usually rises from insufficient and delayed investment in urban water-treatment facilities. Industrial effluent rules are not implemented due to inadequate technical and human resource 
availability with the cities pollution control authorities. A groundwater shortage keeps additional water from flowing into lakes, rivers and seas. This means that over time, less water will enter as the existing surface water continues to evaporate. As the water becomes less deep, it will affect everything in that particular region, including fish and wildlife (Murali, 2018). Essentially, water pollution by sewage is a universal problem which is not confined to rivers running through large cities in the region. Sewage, if not adequately treated and disposed of, poses severe pollution or health problems. The link between public health and clean water and sanitation is clear: the UNDP estimates that a lack of these services results in about half the developing world suffering from a health problem at any given time, and accounts for 1.8 million annual child deaths from diarrhea alone (Seimens, 2018). This indeed is significant burden for economic growth of these countries.

\subsection{Water Depletion}

Rapid economic development and urbanization has resulted in degradation and depletion of natural resources, including water and related ecosystem services (Victor, 2017). The World Economic Forum ranks water crises as the world's third greatest risk by impact and extreme weather the top risk by likelihood. Climate change affects groundwater recharge rates (i.e., the renewable groundwater resources) and depths of groundwater tables. However, knowledge of current recharge and levels in both developed and developing countries is poor; and there has been very little research on the future impact of climate change on groundwater, or groundwater-surface water interactions. Aquifer depletion in agricultural regions could threaten nearly half the world's food sources and deny 1.8 billion people reliable access to water by 2050 . Essentially, the groundwater depletion will force us to pump water from deeper within the Earth. The more we extract groundwater right below the Earth's surface, the further down we have to go in order to get more. As we have to extract water from deeper within the Earth, we find that there is less water available. Often, the existing infrastructure is not adequate to support such rapid urbanization, thus resulting in inadequate potable water supply leading to over-abstraction of groundwater, hence, causing land subsidence which further aggravates the flood problem. Existing water resources in many areas in the region can be considered already fully utilized due to rapid groundwater depletion.

\subsection{Flooding}

Asia and the Pacific have recently experienced some of the most damaging weather- and climate-related disasters, with alarming consequences for human welfare. In the last 10 years alone, it is estimated that 700 million people have died and 1.7 billion have been affected due to serious storms, floods, and heat waves. Floods have also cost the region about $\$ 1.4$ trillion (ADB, 2016). Countries such as the Philippines increasingly experience more intense rather than more frequent extreme events. Extreme flood events in Metro Manila are usually caused by heavy precipitation events lasting over 1 to 3 days generally resulting from typhoons and storm surges. Other causes of flooding are high tide combined with excess runoff from rivers, heavy rains, and sea level rise (Pillai et al., 2010). In addition to natural causes, Pillai et al. (2010) said that the extreme flood 
events are also caused by anthropogenic factors such as: a) reduction in river channel capacity resulting from encroachment of houses, siltation from deforestation, and garbage, b) disappearance of small river channels (esteros), c) reduced infiltration due to urbanization, d) loss of natural retention areas, and e) land subsidence resulting from over extraction of ground water. Drainage canals already clogged with rubbish is a major factor causing severe flooding in the metropolis (Singru and Lindfield, 2014). Likewise, the number of hot days and warm nights is increasing and projected to continue to do so. Such changes coupled with weak resource management and limited data availability further compound water insecurity. Heavy precipitation events are projected to become more frequent over most regions throughout the 21 st century. This would affect the risk of flash flooding and urban flooding.

\section{Quezon City, Philippines Case Study}

A recent study by the Global Water Partnership and Organisation for Economic Co-operation and Development indicates that water insecurity costs the global economy about $\$ 500$ billion annually with a total drag on the world economy of $1 \%$ or more of global gross domestic product (Sadoff et al., 2015). Mainly, the urban development and related water problems in SE Asian cities are viewed as the consequence of climate change variations impact and rapid and uncontrolled urbanization and unsustainable development. These evidences emphasized the link between water insecurity and its negative impact on the economy. Water remains pivotal for sustainable development and is also linked to a number of CC challenges such as local flooding, water shortage and water pollution (ADB, 2016). Thus, equal and inclusive agenda is applied to the Quezon City, Philippines as a pilot urban area and developed corresponding policy objectives, without which, the Sustainable Development Goals (SDGs) and CC themes for universal access to drinking water, sanitation, and hygiene cannot be achieved. As a case study, the collection and analysis of primary data is done in formulating said objectives and strategies with corresponding programs, projects and activities known as Action Plan. The following case study was done by the author and his research fellows in response to extreme weather disastrous impacts and to make urban areas resilient towards Philippines' National Climate Change Action Plan (NCCAP) strategic priorities, primarily water sufficiency (Raza et al., 2018).

\subsection{Objectives of the Case Study}

The research aims to answer the following questions:

- What is the threat level of extreme weather events to Water Sufficiency related elements at risk and their bearing on the five Development Sectors?

- What is Institutional Adaptive Capacity (AC) to understand the impact of extreme weather events on Water Sufficiency related elements at risk?

- What is the Institutional Relative Vulnerability (RV) based on the current threat and corresponding Institutional AC?

- What are the Water Sufficiency crosscutting Development Sectors based Programs, Projects, and Activities (PPAs) in term of Action Plan? 


\subsection{Scope of the Related Literature}

The adaptive capacity is used in the context of CCA to improve adaptive capacity against vulnerability towards the seven strategy areas (i.e., Food Security, Water Sufficiency, Ecological Environmental Stability, Human Security, Climate Smart Industries and Services, Sustainable Energy, and Knowledge and Capacity Development) as prioritized under the National Climate Change Action Plan 2011 - 2028 (CCC, 2011).

Local institutions' coping and adaptive capacities form the basis for assessment of disaster resilience. Local institutions play a critical role in supporting adaptation. Thus, expanding the institutional and personnel's coping and adaptive capacities are the integral parts in creating resilient societies (Grothmann et al., 2013). The Adaptive Capacity Wheel by Gupta et al. (2010) was also considered in identifying institutional assessment parameters.

\subsection{Methodology}

It was done by applying exploratory research method. Primarily, the selection of QC (see Figure 3, left) as the pilot urban area was empirically done by collecting data from all candidate cities using the Key Informative Interviews (KIIs). The specialized Logical Decision for Windows (LDW) software with built-in statistical tool was used to rank and select the top-ranked city as a pilot Local Government Unit (LGU) (see Figure 3, center) (Raza 2016). The ranking results of the candidate cities are shown in Figure 3, right (Raza, 2015).
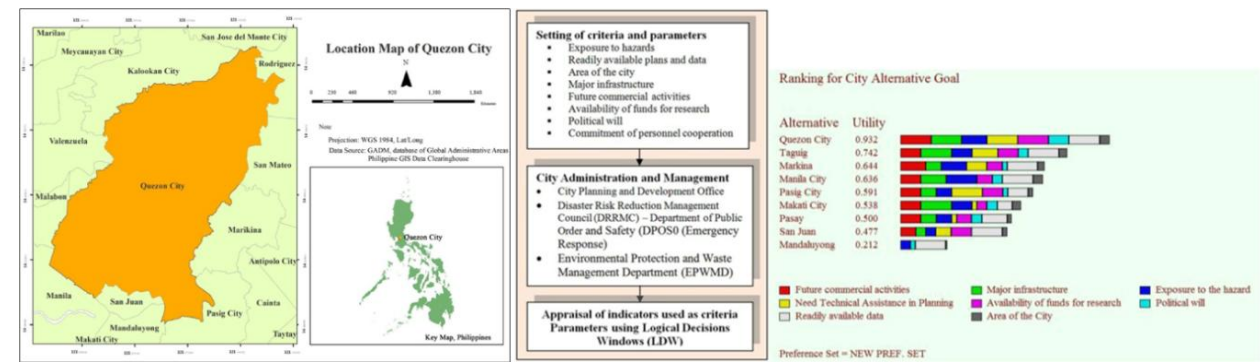

Figure 3. Location Map of QC (left), Framework to select Pilot City (center), and Ranking produced through $L D W$ Software (right).

Further, the equal and inclusive agenda is applied that is comprised of gender-sensitive participatory process done through strategic planning workshops to collect pertinent data in understanding the institutional adaptive capacity in assessing and analyzing QC extreme weather threat level via fill-in-the-blank form (Raza, 2015). The following formula was used to calculate the Relative Vulnerability to Extreme Weather for Water Sustainability:

Relative Vulnerability $=\frac{\text { Threat Level (Based on Exposure and Sensitivity Analysis) }}{\text { Adaptive Capacity (Institutional ) }}$

Geographic Information Systems (GIS) was also used to translate the findings into spatial strategies showing the flood susceptibility, buildings affected by flooding, and critical point facilities affected by flood all in 100-year return period flood scenario. 


\subsection{Findings}

Threat Level and Institutional AC analysis outputs retrieved from data of corresponding fill-in-the-blank forms are shown in

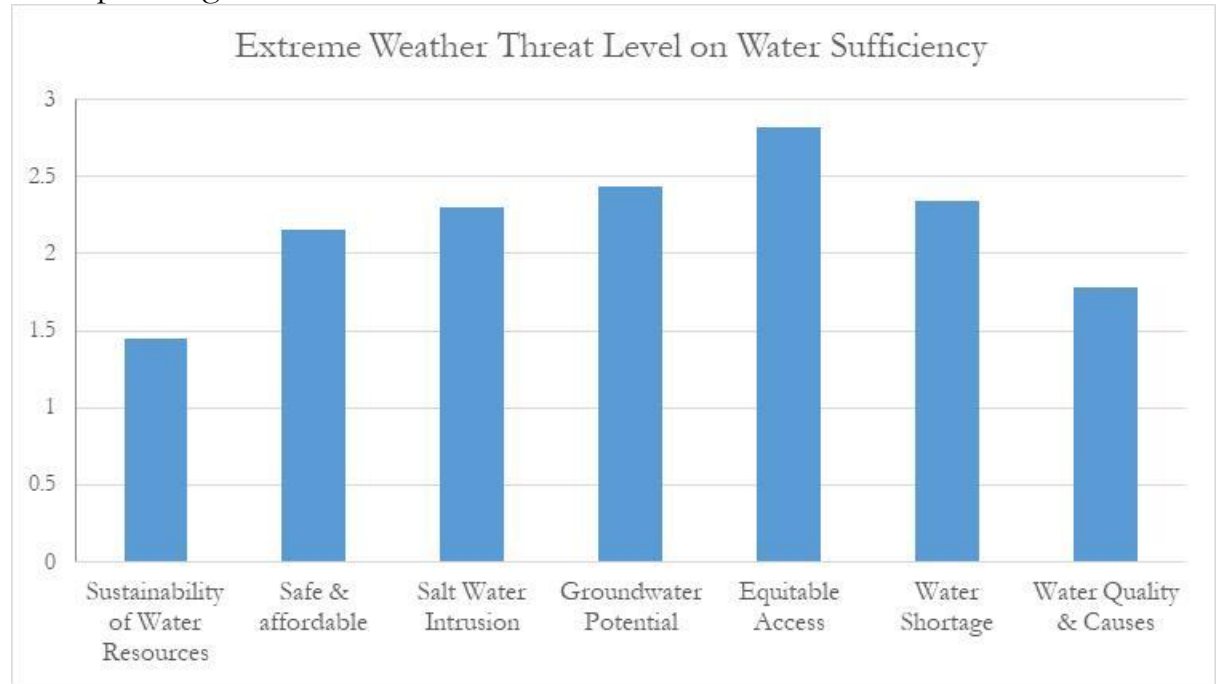

Figure 4 and

\section{Institutional Adaptive Capacity}

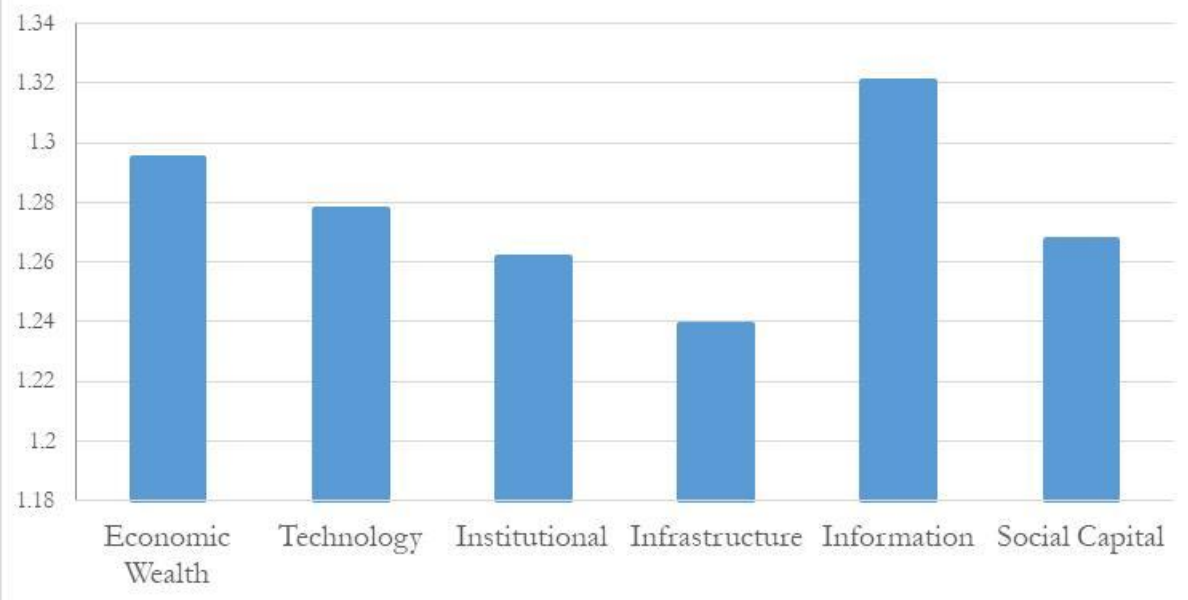

Figure 5 respectively. Further, the calculated RV to Extreme Weather for Water Sustainability is shown in Figure 6. The output of RV ranges from 1-5 is interpreted using a scoring matrix adopted from LCCAP, Guide Process Book 1 (DILG, 2014) shown in Figure 7. 


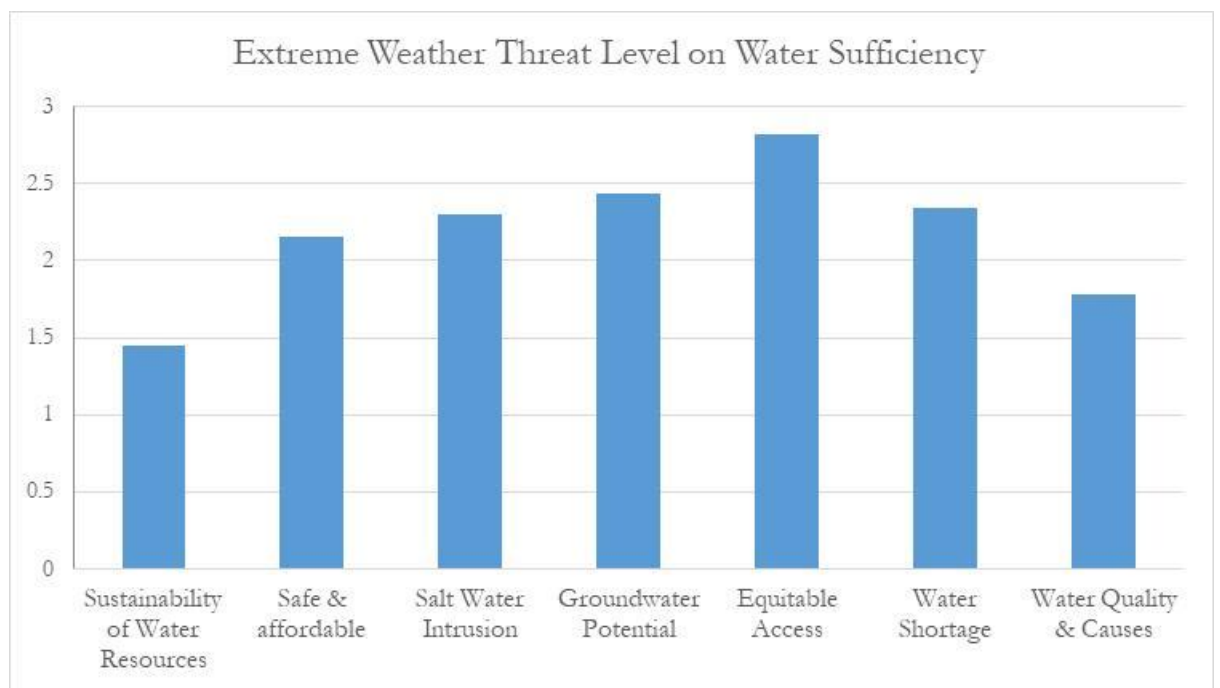

Figure 4. Extreme Weather Threat Level on Water Sufficiency

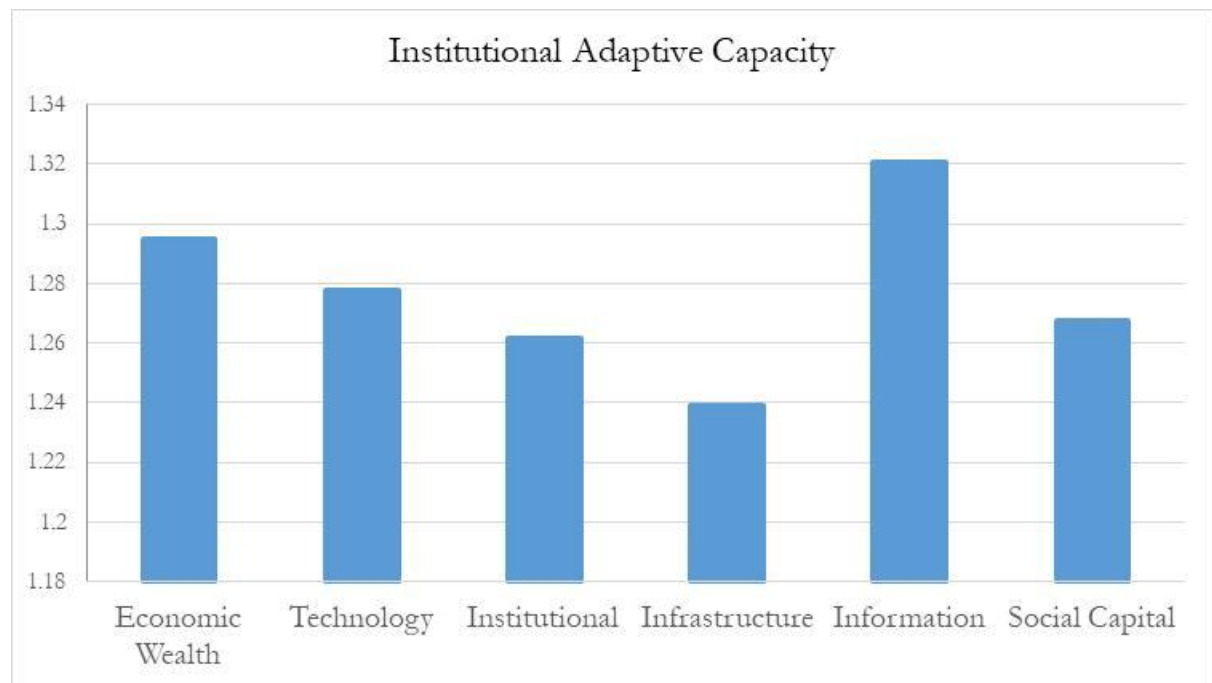

Figure 5. Institutional Adaptive Capacity 


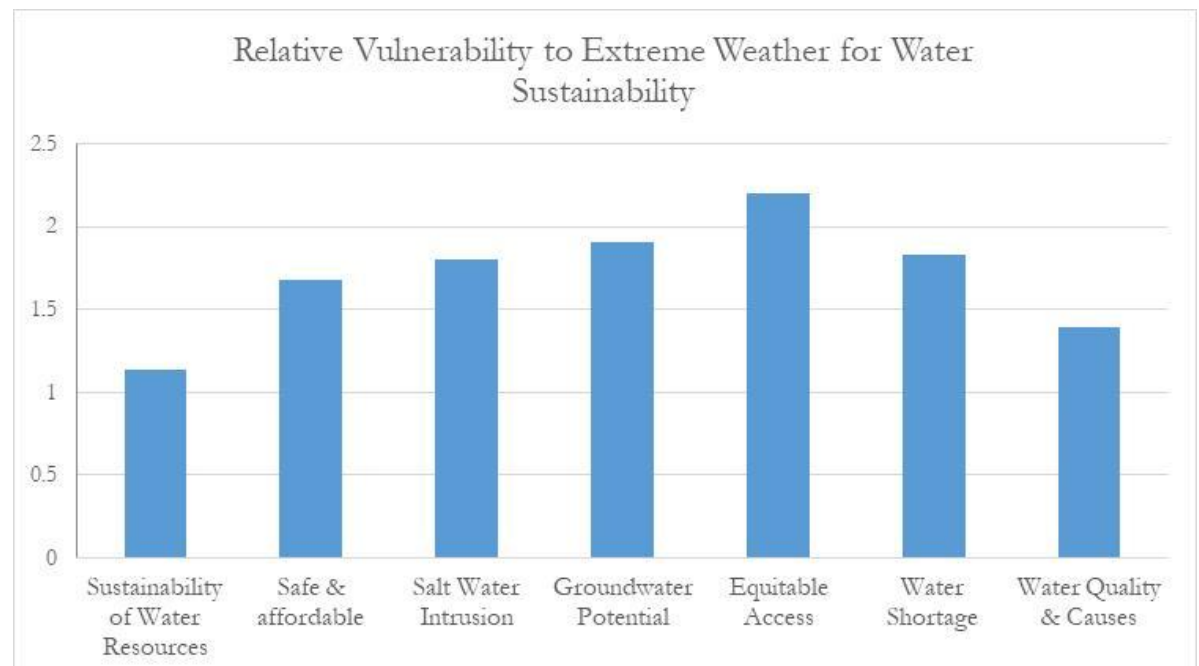

Figure 6. Vulnerability to Extreme Weather for Water Sustainability

\begin{tabular}{|c|c|c|c|c|c|c|}
\hline \multirow{2}{*}{$\begin{array}{l}\text { Threat } \\
\text { Level }\end{array}$} & \multicolumn{5}{|c|}{ Adaptive Capacity Score } & \multirow{2}{*}{$\begin{array}{c}\text { Relative } \\
\text { Vulnerability }\end{array}$} \\
\hline & High (5) & $\begin{array}{l}\text { Medium } \\
\text { High (4) }\end{array}$ & Medium (3) & $\begin{array}{l}\text { Medium } \\
\text { Low (2) }\end{array}$ & Low (1) & \\
\hline High (5) & 1 & 1.25 & 1.66 & 2.5 & 5 & High (4-5) \\
\hline Medium High (4) & 0.8 & 1 & 1.33 & 2 & 4 & $\begin{array}{c}\text { Medium High } \\
(2.1-3.9)\end{array}$ \\
\hline Medium (3) & 0.6 & 0.75 & 1 & 1.5 & 3 & $\underset{(1.5-2)}{\text { Medium }}$ \\
\hline Medium Low (2) & 0.4 & 0.5 & 0.66 & 1 & 2 & $\begin{array}{c}\text { Medium Low } \\
(1.1-1.49)\end{array}$ \\
\hline Low (1) & 0.2 & 0.25 & 0.33 & 0.5 & 1 & Low $(>1)$ \\
\hline
\end{tabular}

Figure 7. Scoring Matrix Adopted from LCCAP, Guide Process Book 1 (DILG, 2014)

The analysis of the data revealed that extreme weather events (100 year return period) will impact sustainability of city water resources; availability of clean, safe, equitable, and affordable water; ground water potential; and projected gastrointestinal infection rate if no adaptation interventions are undertaken.

Further, vulnerability maps are also developed to determine the spatial distribution of water support infrastructure due to the impact of extreme weather events shown in Figure 8 (Flood Susceptibility), Figure 9 (Buildings Affected by Flooding), and Figure 10 (Critical Point Facilities Affected by Flooding) all on based on 100-year flood scenario. 


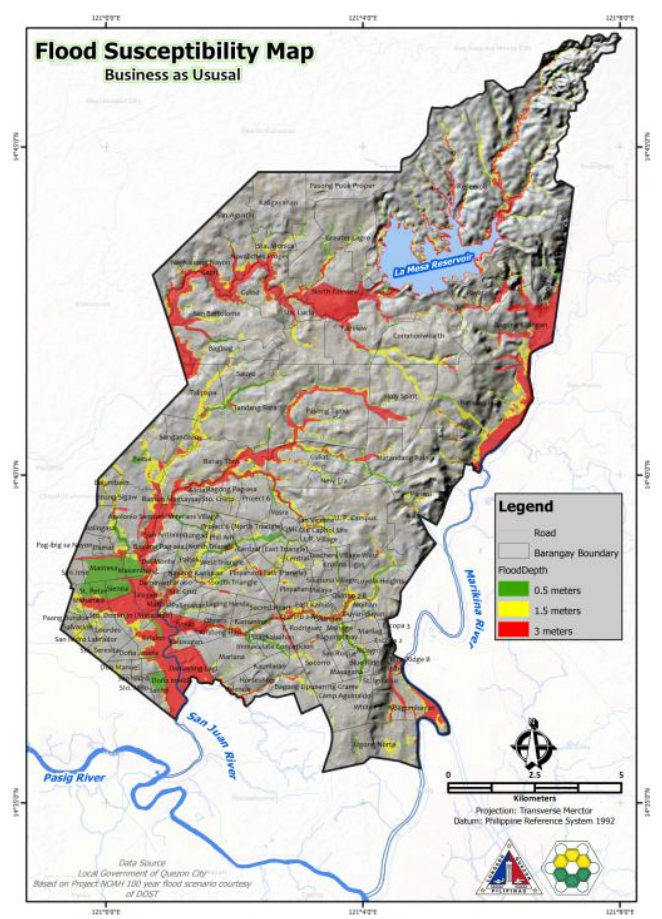

Figure 8. Flood Susceptibility Map

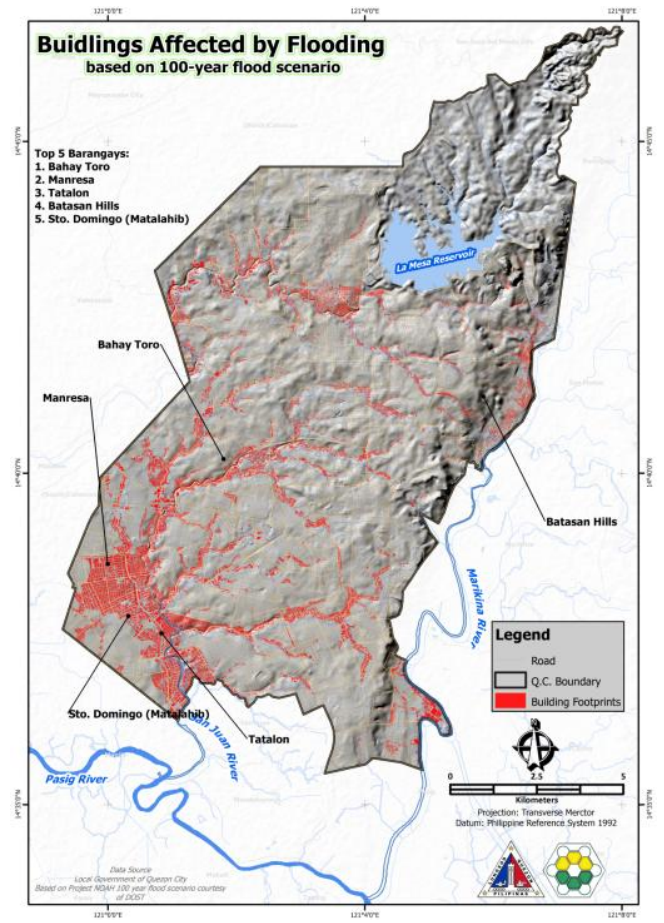

Figure 9. Buildings Affected by Flooding 


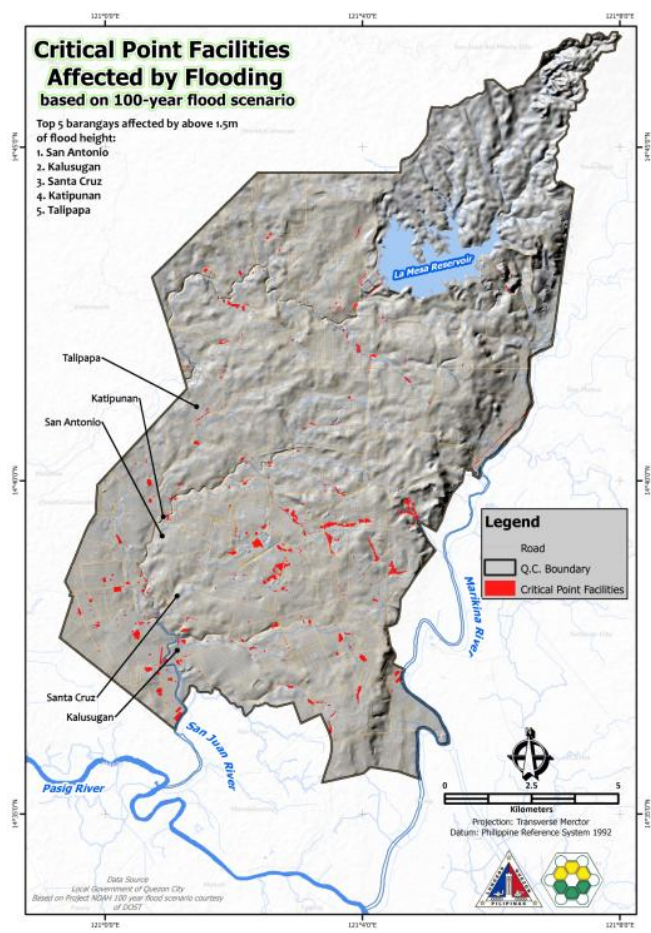

Figure 10. Critical Point Facilities Affected by Flooding

Considering the findings and contribution from the city development council members during a strategic workshop, the following development sector (Social, Economic, Land Use/Infrastructure, Environmental, Institutional) based adaptation action plan is prepared defining 15 Programs, Projects and Activities (PPAs) as solutions for water challenges across five development sectors (Figure 11 to Figure 15).

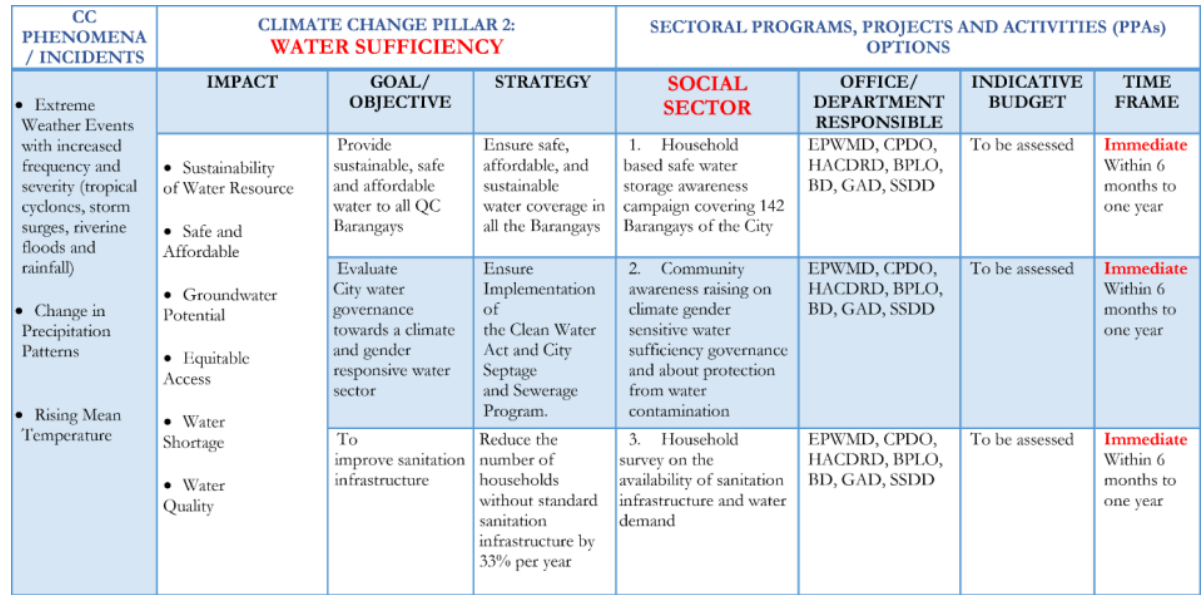

Figure 11. Water Sufficiency PPAs for the Social Development Sector 


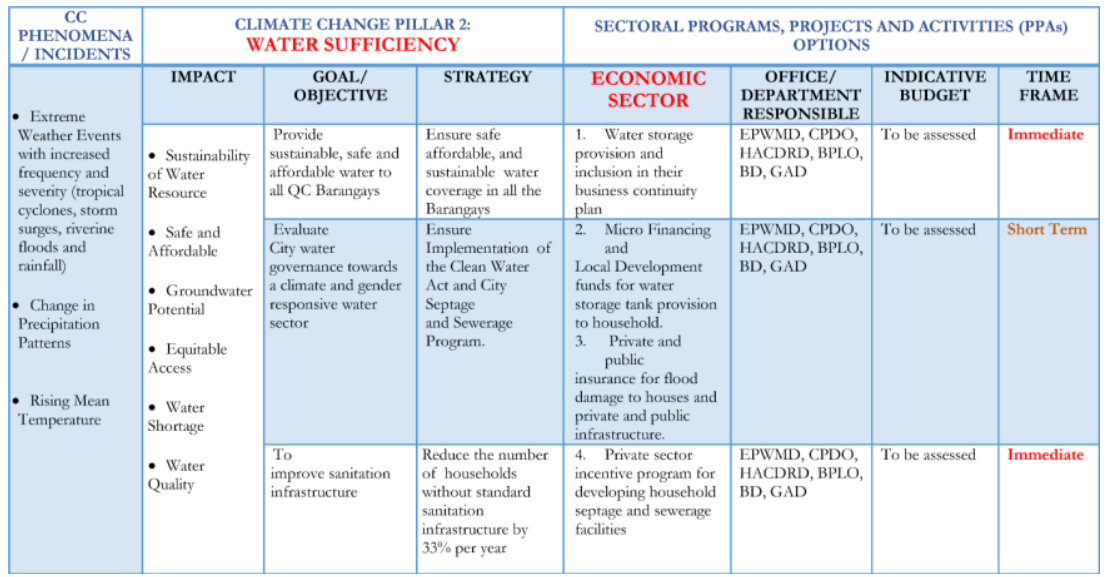

Figure 12. Water Sufficiency PPAs for the Economic Development Sector

\begin{tabular}{|c|c|c|c|c|c|c|c|}
\hline \begin{tabular}{|c} 
CC \\
PHENOMENA \\
/ INCIDENTS
\end{tabular} & \multicolumn{3}{|c|}{$\begin{array}{l}\text { CLIMATE CHANGE PILLAR 2: } \\
\text { WATER SUFFICIENCY }\end{array}$} & \multicolumn{4}{|c|}{$\begin{array}{l}\text { SECTORAL PROGRAMS, PROJECTS AND ACTIVITIES (PPAs) } \\
\text { OPTIONS }\end{array}$} \\
\hline \multirow{4}{*}{$\begin{array}{l}\text { - Extreme } \\
\text { Weather Events } \\
\text { with increased } \\
\text { frequency and } \\
\text { severity (tropical } \\
\text { cyclones, storm } \\
\text { surges, riverine } \\
\text { floods and } \\
\text { rainfall) } \\
\text { - Change in } \\
\text { Precipitation } \\
\text { Patterns } \\
\text { Rising Mean } \\
\text { Temperature }\end{array}$} & IMPACT & $\begin{array}{l}\text { GOAL/ } \\
\text { OBJECTIVE }\end{array}$ & STRATEGY & $\begin{array}{c}\text { LAND USE/ } \\
\text { INFRASTRUCTURE } \\
\text { SECTOR }\end{array}$ & $\begin{array}{c}\text { OFFICE/ } \\
\text { DEPARTMENT } \\
\text { RESPONSIBLE }\end{array}$ & $\begin{array}{l}\text { INDICATIVE } \\
\text { BUDGET }\end{array}$ & $\begin{array}{l}\text { TIME } \\
\text { FRAME }\end{array}$ \\
\hline & $\begin{array}{l}\text { - Sustainability } \\
\text { of Water } \\
\text { Resource } \\
\text { - Safe and } \\
\text { Affordable }\end{array}$ & $\begin{array}{l}\text { Provide } \\
\text { sustainable, safe } \\
\text { and affordable } \\
\text { water to all QC } \\
\text { Barangays }\end{array}$ & $\begin{array}{l}\text { Ensure safe } \\
\text { affordable, and } \\
\text { sustainable } \\
\text { water coverage } \\
\text { in all the } \\
\text { Barangays }\end{array}$ & $\begin{array}{l}\text { 1. Structural flexibility } \\
\text { including the stratcgic use of } \\
\text { valves during emengency by } \\
\text { laying pipes that can be } \\
\text { moved and changed to } \\
\text { accommodate various } \\
\text { households }\end{array}$ & $\begin{array}{l}\text { EPWMD/CCMA } \\
\text { Unit, DRRMC, } \\
\text { CPDO, CFID }\end{array}$ & To be assessed & $\begin{array}{l}\text { Medium } \\
\text { Term }\end{array}$ \\
\hline & $\begin{array}{l}\text { - Groundwater } \\
\text { Potential } \\
\text { - Equitable } \\
\text { Access } \\
\text { - Water } \\
\text { Shortage }\end{array}$ & $\begin{array}{l}\text { Evaluate } \\
\text { City water } \\
\text { governance } \\
\text { towards a climate } \\
\text { and gender } \\
\text { responsive water } \\
\text { sector }\end{array}$ & $\begin{array}{l}\text { Ensure } \\
\text { Implementation } \\
\text { of } \\
\text { the Clean Water } \\
\text { Act and City } \\
\text { Septage } \\
\text { and Sewerage } \\
\text { Program. }\end{array}$ & $\begin{array}{l}\text { 2. Built-in structural } \\
\text { measures along water ways to } \\
\text { prevent flooding and } \\
\text { introduce standard sewerage } \\
\text { system facilities, and water } \\
\text { harvesting schemes to the } \\
\text { city stakeholders. }\end{array}$ & $\begin{array}{l}\text { EPIWMD/CCMA } \\
\text { Unit, DRRMC, } \\
\text { CPDO, CFD }\end{array}$ & To be assessed & $\begin{array}{l}\text { Medium } \\
\text { Term }\end{array}$ \\
\hline & - Water & \begin{tabular}{|l|} 
To \\
improve sanitation \\
infrastructure
\end{tabular} & $\begin{array}{l}\text { Reduce the } \\
\text { number of } \\
\text { households } \\
\text { without standard } \\
\text { sanitation } \\
\text { infrastructure by } \\
33 \% \text { per year }\end{array}$ & $\begin{array}{l}\text { 3. Built house for } \\
\text { disposal sanitation } \\
\text { infrastructure to support } \\
33 \% \text { of households } \\
\text { demanded sanitation } \\
\text { facilities per Barangay }\end{array}$ & $\begin{array}{l}\text { EPWMD/CCMA } \\
\text { Unit, DRRMC, } \\
\text { CPDO, CED }\end{array}$ & To be assessed & $\begin{array}{l}\text { Medium to } \\
\text { Long } \\
\text { Term }\end{array}$ \\
\hline
\end{tabular}

Figure 13. Water Sufficiency PPAs for the Land Use/Infrastructure Development Sector

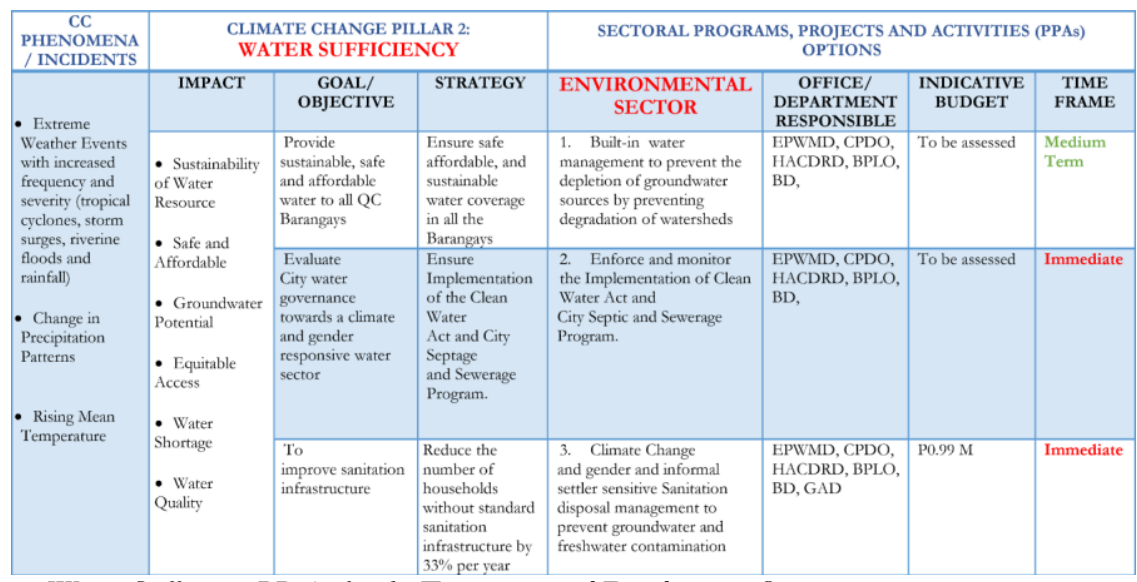

Figure 14. Water Sufficiency PPAs for the Environmental Development Sector 


\begin{tabular}{|c|c|c|c|c|c|c|c|}
\hline \begin{tabular}{|c} 
CC \\
PHENOMENA \\
/ INCIDENTS
\end{tabular} & \multicolumn{3}{|c|}{$\begin{array}{l}\text { CLIMATE CHANGE PILLAR 2: } \\
\text { WATER SUFFICIENCY }\end{array}$} & \multicolumn{4}{|c|}{$\begin{array}{l}\text { SECTORAL PROGRAMS, PROJECTS AND ACTIVITIES (PPAs) } \\
\text { OPTIONS }\end{array}$} \\
\hline \multirow{2}{*}{$\begin{array}{l}\text { - Extreme } \\
\text { Weather Events } \\
\text { with increased } \\
\text { frequency and } \\
\text { severity (tropical } \\
\text { cyclones, storm } \\
\text { surges, riverine } \\
\text { floods and } \\
\text { rainfall) }\end{array}$} & IMPACT & $\begin{array}{c}\text { GOAL/OBJECT } \\
\text { IVE }\end{array}$ & STRATEGY & $\begin{array}{l}\text { INSTITUTIONAL } \\
\text { SECTOR }\end{array}$ & $\begin{array}{c}\text { OFFICE/ } \\
\text { DEPARTMENT } \\
\text { RESPONSIBLE }\end{array}$ & $\begin{array}{l}\text { INDICATIVE } \\
\text { BUDGET }\end{array}$ & $\begin{array}{l}\text { TIME } \\
\text { FRAME }\end{array}$ \\
\hline & \multirow{2}{*}{$\begin{array}{l}\text { - Sustainability } \\
\text { of Water } \\
\text { Resource } \\
\text { - Safe and } \\
\text { Affordable } \\
\text { - Groundwater } \\
\text { Potential }\end{array}$} & $\begin{array}{l}\text { Provide } \\
\text { sustainable, safe } \\
\text { and affordable } \\
\text { water to all QC } \\
\text { Barangays }\end{array}$ & $\begin{array}{l}\text { Ensure safe } \\
\text { affordable, and } \\
\text { sustainable water } \\
\text { coverage in all } \\
\text { the Barangays }\end{array}$ & $\begin{array}{l}\text { 1. Create Competent } \\
\text { Climate Change Mitigation } \\
\text { and Adaptation Unit } \\
\text { within the existing QCG } \\
\text { System }\end{array}$ & $\begin{array}{l}\text { EPWMD/CCMA } \\
\text { Unit, DRRMC, } \\
\text { CPDO, CED }\end{array}$ & $\mathrm{P} 0.99 \mathrm{M}$ & Immediate \\
\hline $\begin{array}{l}\text { floods and } \\
\text { rainfall) } \\
\text { - Change in } \\
\text { Precipitation } \\
\text { Patterns }\end{array}$ & & \begin{tabular}{|l|} 
Evaluate \\
City water \\
governance \\
towards a climate \\
and gender \\
responsive water \\
sector
\end{tabular} & $\begin{array}{l}\text { Ensure } \\
\text { Implementation } \\
\text { of } \\
\text { the Clean Water } \\
\text { Act and City } \\
\text { Septage } \\
\text { and Sewerage } \\
\text { Program. }\end{array}$ & $\begin{array}{l}2 . \quad \text { Evaluate the existing } \\
\text { Climate adaptive capacity } \\
\text { towards safe water supply } \\
\text { and sanitation facilities }\end{array}$ & $\begin{array}{l}\text { EPWWM/CCMA } \\
\text { Unit, DRRMC, } \\
\text { CPDO, CED }\end{array}$ & P0.5 M & Immediate \\
\hline $\begin{array}{l}\text { - Rising Mean } \\
\text { Temperature }\end{array}$ & $\begin{array}{l}\text { - Water } \\
\text { Shortage } \\
\text { - Water } \\
\text { Quality }\end{array}$ & \begin{tabular}{|l|} 
To \\
improve sanitation \\
infrastructure
\end{tabular} & $\begin{array}{l}\text { Reduce the } \\
\text { number of } \\
\text { households } \\
\text { without standard } \\
\text { sanitation } \\
\text { infrastructure by } \\
33 \% \text { per year }\end{array}$ & $\begin{array}{l}\text { 3. Support existing } \\
\text { sanitation infrastructure } \\
\text { and upgrade pertinent } \\
\text { sanitation infrastructure } \\
\text { demand yearly }\end{array}$ & $\begin{array}{l}\text { EPUWD/CCMA } \\
\text { Unit, DRRMC, } \\
\text { CPDO, CED }\end{array}$ & To be assessed & $\begin{array}{l}\text { Short } \\
\text { Term }\end{array}$ \\
\hline
\end{tabular}

Figure 15. Water Sufficiency PPAs for the Institutional Development Sector

\subsection{Conclusion of the Case Study}

All buildings and critical point facilities in red for both maps (Figure 8 and Figure 9) portray that the related water support infrastructure is also considered affected. The formulation of development sector based Action Plan considered the perception of the city development council members who are the same people who also responded the fill-in-the-blank forms during assessment of the threat level and institutional AC. It has to be noted that the overall RV is "Medium" based on the data collected from the respondents and analysis of the data. However, the maps produced show substantial numbers of affected structures, usually meaning "High" RV. Thus, the respondents need more understanding about improving their perception towards identifying threat levels to match with spatial distribution of the impact.

\subsection{Recommendations of the Case Study}

A more detailed study should be done where the entire water infrastructure including underground water infrastructure length, depth, and material is available in GIS format to estimate the real cost of potential damages since in this analysis, the assumption was the corresponding water infrastructure is also damaged.

The Immediate-term PPAs should be implemented in less than 1 year; Short-term PPAs to be completed in 1-3 years; Medium-term PPAs to be done in 4-6 years; and Longterm PPAs need to be executed in 7 years.

\section{Conclusion}

Even if we are able to increase water productivity, there are major challenges ahead. With an increasing population and its welfare, expected spatial and temporal changes in water availability due to climate change, and the need to restore our aquatic ecosystems, we are facing a huge task while the easy solutions are already being implemented (ADB, 2016). However, replenishing groundwater and treating or disposing sewage require huge funds which cities like Manila, Bangkok, Jakarta, and, to a certain extent, Kuala Lumpur, would rather spend on other immediate benefits (Sim and Balamurugan, 1989). These problems are expected to worsen unless serious science 
based planning and management are carried out. Certainly, Knowledge and information lead to sound policies to guide proper investments in water management, which subsequently lead to economic growth. It has to be noted that the existing urban conditions in SE Asian cities do not allow for environmental revival unless extensive funds are utilized for major urban improvements, such as for sewerage, water supply, and waste disposal.

\section{Recommendations}

In this regard, the following recommendations are made:

- A policy must be formulated to prevent the growth of slums, squatters, high unemployment, poor amenity, and uncontrolled depletion of urban land resources as these lead to degradation of rivers and drainage networks due to sedimentation, garbage disposal, and damages to drains and culverts.

- There is need to evaluate the existing city demand by its smallest political unit and existing capacity to provide safe water supply, sanitation facilities, and flood prevention. This should be done by a project to provide or upgrade infrastructure for pertinent sanitation and safe water supply. It will also identify built-in structural measures along waterways to prevent flooding and introduce standard sewerage system facilities and water harvesting schemes to the city stakeholders.

- Built-in integrated water management system to prevent the depletion of groundwater sources by preventing degradation of watersheds. Further, Climate Change, gendersensitive governance, and informal settler sensitive sanitation disposal management to prevent groundwater and freshwater contamination should be taken in to account for this project.

- Water storage provision and inclusion should be included in business continuity plans for industry and agriculture sectors. Micro-Financing and Local Development funds for water storage tank provision to households should be considered. Private and public insurance for flood damage to houses and infrastructures should be considered. Further, raising community awareness on climate gender-sensitive water sufficiency governance and protection from water contamination should be part of this project.

- As aquifers and other groundwater sources are depleted at a rate greater than the recharge rate, artificial recharge is needed to maintain a lasting water supply to prevent complete withdrawal of groundwater in the near future. To combat over-pumping of groundwater and achieve stability in the water table, artificial recharge is another water source that will help alleviate the stress on groundwater supply is needed. Murali (2018) suggests various artificial recharge mechanisms that include, among others, roof top rain water, runoff harvesting through recharge pit, recharge trench, tube-well, recharge well, Rain Water Harvesting through Gully Plug, Contour Bund, Gabion Structure, Percolation tank, Check Dam, Cement Plug, and Recharge shaft. Further, Dugwell Recharge Ground Water Dams, Subsurface Dyke can also be considered based on the area and cause of the depletion.

- The 'Policy Brief report suggests that in order to tackle this issue and to foster an effective approach for sustainable urban development in the region, policymakers in collaboration with the private sector and the international donor community must adopt 
an integrated approach for protecting urban water bodies, including by developing relevant legal frameworks and enforcement mechanisms.

To achieve the above objectives, the following proposed Action Points need to be considered:

- Urban water sufficiency; provide water security and achieve sustainable, safe, and affordable water supply systems. It also includes establishing gender-sensitive urban water governance.

- Mainstreaming Disaster Risk Reduction and Climate Change Adaptation for in-house water security, sanitation infrastructure improvement, and reducing spread of waterborne diseases by applying sustainable development guiding principles.

- Economic and environmental water security, segregated by the source to allow for specific analysis for the sustainability of groundwater use. Further, identification of infrastructure projects to promote river water health monitoring at the basin level.

\section{References}

Asian Development Bank (ADB) Blog. (2013). Facing Nature's Wrath: Dealing with Climate Change and Its Effects. Retrieved from http://blogs.adb.org/chats/facingnatures-wrath-dealing-climate- changeand-its-effects [Accessed 6 Dec. 2013].

Climate Change Commission (CCC) (2011). National Climate Change Action Plan 2011-2028. Philippines: Climate Change Commission.

Department of Interior and Local Government (DILG) (2014). LGU Guidebook on the Formulation of Local Climate Change Action Plan (LCCAP), Book 1.

Grothmann, T., Grecksch, K., Winges, M., and Siebenhüner, B. (2013). Assessing institutional capacities to adapt to climate change: Integrating psychological dimensions in the Adaptive Capacity Wheel. Natural Hazards and Earth System Sciences, 203.

Gupta, J., Termeer, C., Klostermann, J., Meijerink, S., van den Brink, M., Jong, P., Nooteboom, S. and Bergsma, E. (2010). The adaptive capacity wheel: a method to assess the inherent characteristics of institutions to enable the adaptive capacity of society. Environmental Science \& Policy, 13(6), pp.459-471.

International Institute for Applied Systems Analysis (IIASA) (2016). Water Futures and Solutions: Asia 2050. Vienna. (under publication).

Murali (2018). Depleting groundwater: Causes, effects, solution. City Today. Mysuru Today.

National Oceanic and Atmospheric Administration (NOAA) (2018). Climate Change and Variability. National Center for Environmental Information. Retrieved from https://www.ncdc.noaa.gov/climate-information/climate-change-and-variability [Accessed 20 Jun. 2019].

Pillai, P., Philips, B.R., Shyamsundar, P., Ahmed, K., Wang, L. (2010). Climate risks and adaptation in Asian coastal megacities: a synthesis report (English). Washington, DC: World Bank.

Quezon City Government (QCG) and UP Planning and Development Research Foundation (UP PLANADES) (2017). Quezon City Local Climate Change Action Plan 2017-2027, Consulting Services for Climate Change Mitigation and Adaptation for Quezon City Stakeholders (CSCCMA), Project No. 1610-50286, Consolidated Report. Quezon City, Philippines.

Quezon City Government (QCG) and UP Planning and Development Research Foundation (UP PLANADES) (2017). Quezon City Local Climate Change Action Plan 2017-2027, Consulting Services for Climate Change Mitigation and Adaptation for Quezon City Stakeholders (CSCCMA), Project No. 1610-50286, Consolidated Report. Quezon City, Philippines.

Raza, T. (2015). Risk sensitive land use and development planning model: mainstreaming DRR and CCA into planner's and decision agenda, Quezon City, Philippines. Ph. D. dissertation. School of Urban and Regional Planning, University of the Philippines, Quezon City, Philippines. p. 84. 
Raza, T., Fan-Sheng, K., and Peralta, J. (2016). Originating Urban Climate Change Adaptation Planning Guidepost: Urban Landscape Sustainability Framework (ULSF), Quezon City, Philippines. Proceedings of the 11th International Symposium on Architectural Interchanges in Asia h ISAIA (2016), pp. 2073 - 2078, Miyagi, Japan.

Raza, T., Rentoy, F., Andres, A.V., Vinarao, V., Raza, T.K., and Espinosa, R.I. (2018). Enhancing Urban Resilience towards Water Sufficiency during Extreme Weather Disastrous Impact: Sectoral Adaptation Action Plan of Quezon City, Philippines. International Conference 'Water Science for Impact'. Wageningen University and Research, the Netherlands.

Sadoff, C.W., Hall, J.W., Grey, D., Aerts, J.C.J.H, Ait-Kadi, M., Brown, C., Cox, A., Dadson, S., Garrick, D., Kelman, J., McCornick, P., Ringler, C., Rosegrant, M., Whittington, D., and Wiberg, D. (2015). Securing Water, Sustaining Growth: Report of the GWP/OECD Task Force on Water Security and Sustainable Growth. Oxford, UK: University of Oxford.

Siemen AG Corporate Communications (n.d.). Megacity Challenges, A stakeholder perspective, A research project conducted by GlobeScan and MRC McLean Hazel, Sponsored by Siemens, Siemens AG Corporate Communications (CC) Wittelsbacherplatz 2, 80333. Retrieved from https://w3.siemens.co.uk/mobility/uk/en/rail_solutions/DC/Documents/MegaCity.pdf [Accessed 20 Jun. 2019].

Sim, L.K. and Balamarugan, G. (1989). Urbanization and Urban Water Problems in Southeast Asia a Case of Unsustainable Development. Journal of Environmental Management. Vol. 32. pp. 195-209.

Singru, R. N. and Lindfield, M. (2014). Republic of the Philippines National Urban Assessment. Asian Development Bank. Mandaluyong City, Philippines.

Victor. P. (2017). Southeast Asia's stream of polluted rivers. The Asean Post. Retrieved from https://theaseanpost.com/article/southeast-asias-stream-polluted-rivers [Accessed 20 Jun. 2019]. 